\title{
An Analysis of Students Error In Solving PISA 2012 And Its Scaffolding
}

\author{
Yurizka Melia Sari ${ }^{1)}$, Erik Valentino ${ }^{2)}$ \\ 1) STKIP Bina Insan Mandiri \\ ${ }^{2)}$ STKIP Bina Insan Mandiri \\ Corresponding author:yurizka.m.sari@gmail.com
}

\begin{abstract}
Based on PIS A survey in 2012, Indonesia was only placed on 64 out of 65 participating countries. The survey suggest that the students' ability of reasoning, spatial orientation, and problem solving are lower compare with other participants countries, especially in Shouth East Asia. Nevertheless, the result of PIS A does not elicit clearly on the students' inability in solving PIS A problem such as the location and the types of student's errors. Therefore, analyzing students' error in solving PIS A problem would be essential countermeasure to belp the students in solving mathematics problems and to develop scaffolding. Based on the data analysis, it is found that there are 5 types of error which is made by the subject. They consist of reading error, comprehension error, transformation error, process skill error, and encoding error. The most common mistake that subject do is encoding error with a percentage of $26 \%$. While reading is the fewest errors made by the subjects that is only 12\%. The types of given scaffolding was explaining the problem carefully and making a summary of new words and find the meaning of them, restructuring problem-solving strategies and reviewing the results of the completion of the problem.
\end{abstract}

Keywords: Analysis of Student's Error, PISA, Newman Analysis, Scaffolding.

\section{Introduction}

Program for International Student Assessment (PISA) is a program to assess the ability of students within the scope of the International. Furthermore, PISA is managed by the Organization for Economic Cooperation and Development (OECD) which is assessed is the student's ability to apply mathematics in a variety of situations in everyday life. Therefore, the measuring instrument used by PISA is a real problem that requires the ability for reasoning, spatial or problem-solving (OECD, 2013a). Moreover, the subject of PISA assessment are students aged about 15 years (OECD, 2013a). Thus age is chosen because students are nearing the end of compulsory education in countries that are members of the OECD (OECD, 2013a), including Indonesia. In addition, the results show that Indonesia only ranks 63 rd out of 64 participant's countries in mathematics with the acquisition of 375 points.

The focus domain of PISA 2012 is mathematics content which are different with three year pattern ago that are focusing on reading, mathematics and science literacy. Furthermore, In 2012, there is an optional component on financial literacy and The mathematics assessment for 2012 will have an optional computer-administered component, which will provide new opportunities for presentations of items and may also test some aspects of doing mathematics assisted by a computer (Stacey, 2011). The 
objective of PISA is to measure what student have learned at school focused on their analysing and reasoning skill when they can solve and interpret situation in daily life.

In fact, the difficulties experienced by students in solving PISA problem due to the lack of student skills in transforming daily life sentences into mathematics sentences. This is also supported by the teacher's role in learning where they do not realize that the mistakes made by the students during this time due to his role in the learning process of mathematics. Teachers only give formulas and exercise problem without connecting them to the situations of everyday life with mathematical concepts. Fiangga (2014) stated that providing formula too early is mostly done by the teacher in teaching mathematics. In fact, the students are still incapable to fully understand what the formula is. This situation is called the mismatch situation.

Wijaya (2015) argue that the difficulties encountered by students can not be separated by contextual problems. It shows that student are limited to learn contextual problem which has similarities with the content of PISA 2012 especially when they have to interpret data presentation on the task or assignment. The importance of giving PISA problem often forgotten by the teachers due to the time limitation of courses. Hence, they decided use the simple problem which have the direct formula for solving it. As a result, students become confused and make the same mistakes when given about the PISA problem to the next level.

In the other hand, scaffolding or support by teachers have done a lot of learning time to improve students' understanding of mathematics and minimize mistakes. However, assistance is given less attention to the teacher student mistake location. As a result, when students are given a similar PISA problem which is they get rarely, the student will bring his mistake when solving on math routines into similar non-routine PISA problems.

Seeing exposure to these facts, it is certainly important for Indonesia to improve scores on PISA in subsequent years. For these improvements, researchers are interested to analyze students' errors in solving PISA problems, especially in mathematics. From this analysis, students will be given scaffolding customized based on the location of the mistakes. These activities will give an idea of the students thinking in solving PISA is based on analysis of errors and giving the given scaffolding. These results can then be used as a reference for improvement planning and ability in mathematics in PISA level.

\section{Research Methods}

This study is an exploratory study with qualitative approach that will produce descriptive data in the form of an idea about the type and location of student's errors in solving PISA 2012. In this study, researchers act as observers and interviewers to determine students' mistakes in solving PISA 2012. There are five characteristics of qualitative research, namely (1) the collection of data in a narrative and visual, (2) setting the background is natural, (3) the researcher is part of the research, (4) The data analysis was performed inductively, and (5) researchers avoid early conclusions (Gay, 2011).

This research is conducted at SMP Muhammadiyah 17 Surabaya in the even semester 2015/2016. As for the students who are the subject of research is the grade 8 students of the selected school. The selected subject based conformity with the objectives PISA study that students who are approaching the age of 15 years or who are taking compulsory. The research subject is determined based on the results of their result in solving PISA 2012, which consisted of four questions which is adjusted to each context PISA 2012.

In this study, the main instrument in the study are researchers because they act as a determinant in the process of research, design conveys research and action research providers. In addition, researchers also act as observers and data collectors in the field, 
such as in-depth interviews on the subject to get the necessary information in data collection.

As for the supporting instruments of this study, namely PISA 2012 test and interview guidelines. The former of supporting instrument consists of four problems which is chosen based on the context of PISA 2012 such as personal, scientific, social and occupational. The latter, interview guidelines prepared as a supporting instrument to identify the students errors in solving PISA 2012 and to explore the reasons behind the mistakes made by the students.

The instrument has been designed granted to the validator to be examined according to their expertise, and then revised with the advice given to produce a valid instrument for use in data retrieval. The instrument is said to be valid if at least two validators agree that such instruments are eligible for using. Once the instrument is validated by the validator, tested the readability of the instrument. Legibility test done to students in grade 8 who are not the subject of research. The purpose of this readability test is to determine whether the instruments used can be understood by students. If students have not been able to understand the questions in the instruments, the researchers make improvements and consulted with experts or specialists. However, if students already understand the questions contained in the instrument of test PISA 2012 and interview guides eligible for used.

The data analysis of this study refers to the stage of qualitative data analysis by Miles and Huberman (Sugiyono, 2010) as follows:

1. Data reduction phase

This process is a form of analysis that refers to the sharpening process, selecting, focus and transform the raw data obtained from the field. Moreover, the data selected are simplified, then grouped with data in accordance with the requisite to answer the research questions.

2. Exposure Data Phase

This stage includes classifying and identifying the data set is organized in the form of narrative text, charts and others, hence making it possible to draw conclusion. So the reduced data will be classified and identified allowing researchers to draw conclusions on the analysis of students' errors in solving PISA 2012 with reference to the Newman error analysis.

3. Drawing Conclusion Phase

From the obtained data, the next activity will be drawing conclusions and verification of these data. After that the researchers conduct further verification in order to check their conclusions with the results of the analysis. Thus, it is obtained the analysis of students' errors and its scaffolding in solving PISA 2012 based on Newman error analysis

\section{Results and Discussion}

Text The results of this study are the type of errors made by five research subject in solving PISA 2012 with different contexts and its scaffolding based on the Newman error analysis Newman . To determine the validity of research data, researchers used the triangulation that is comparing and checking the degree of confidence behind the information obtained through different sources. The distance between the first and second data retrieval adjusted to the readiness of the subject and the researcher. Data validation study performed by comparing data written test and interview.

Based on their general response in solving PISA problem with 5 different context, the most mistake that have been done by them is encoding error with percentage of $26 \%$. Then, the another error that has the lowest percentage is reading error with $12 \%$. While, 
$24 \%$ of mistakes are process skill error and transformation error. The remaining $14 \%$ of the made mistakes is comprehension error.

In the other hand, the PISA context which has the most error is scientific context with a percentage of $43 \%$. Meanwhile, occupational context problem has the less mistake that is only $12 \%$. Then, personal context problem and social context problem consequtive has an error percentage of $21 \%$ and $24 \%$.

Table 1. Error's Analysis of All Students Responses

\begin{tabular}{|c|c|c|c|c|c|}
\hline \multirow[b]{2}{*}{ Type of error } & \multicolumn{4}{|c|}{ Test Item } & \multirow[t]{2}{*}{ Tota } \\
\hline & $\begin{array}{c}1 \\
\text { (Social Context) }\end{array}$ & $\begin{array}{c}2 \\
\text { (Occupation } \\
\text { al Context) }\end{array}$ & $\begin{array}{c}3 \\
\text { (Personal } \\
\text { Context) }\end{array}$ & $\begin{array}{c}4 \\
\text { (Scientific } \\
\text { Context) }\end{array}$ & \\
\hline Reading & 0 & 0 & 2 & 3 & 5 \\
\hline Comprehension & 2 & 0 & 0 & 4 & 6 \\
\hline Transformation & 3 & 1 & 2 & 4 & 10 \\
\hline Process Skill & 3 & 2 & 2 & 3 & 10 \\
\hline Encoding & 2 & 2 & 3 & 4 & 11 \\
\hline $\begin{array}{l}\text { The number of } \\
\text { errors }\end{array}$ & 10 & 5 & 9 & 18 & 42 \\
\hline
\end{tabular}

Explanation:

\begin{tabular}{|l|l}
\hline & $:$ Uncorect Student's Response with Newman's Error Analysis \\
& $:$ Correct Student's Response \\
& $:$ No Response
\end{tabular}

\section{- Reading error}

In this study, subjects do mistake in reading the main information of the problem hence they did not apply its information in solving problem. Moreover, reading error done by subjects in scientific and personal context of PISA problem.

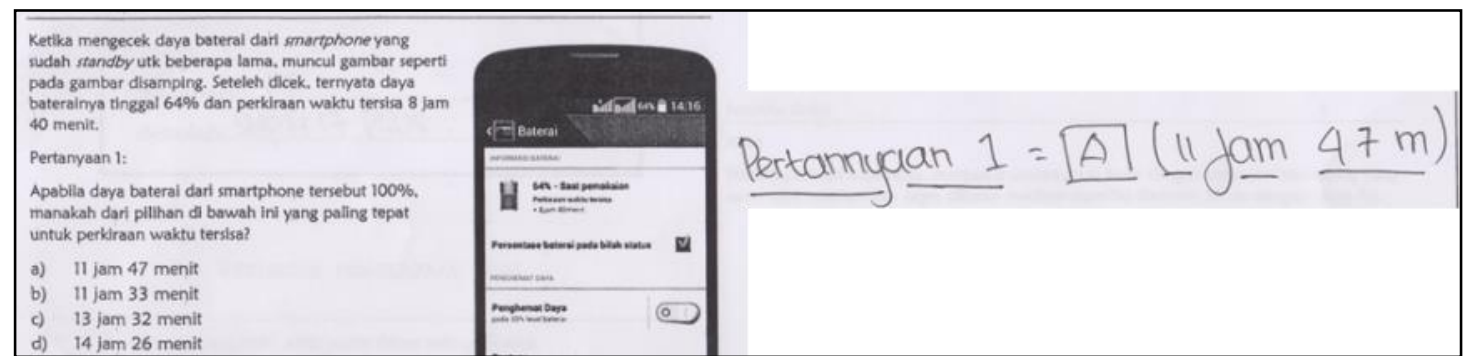

Figure 1. SD's Response on Scientific Context of PISA

Based on the results of the problem revealed that the subject just directly choose the answer without writing down what is known, asked and step solution. 
Type of the given scaffolding is explaining by asking him to read the questions carefully and making a summary of new words and find the meaning of the word. Then, giving scaffolding reviewing by asking subjects to improve their solving process.

\section{- Comprehension error}

In solving PISA problem, subject perform comprehension error on the saintific and social context of PISA problem. In the following is the subject's response on those context with the explanation. One of the example is SC make a mistake in comprehending PISA problem on social context. Based on the interview, SC missunderstand with what question ask about "menguntungkan'. Therefore, subject got confused in writing an appropriate solution.

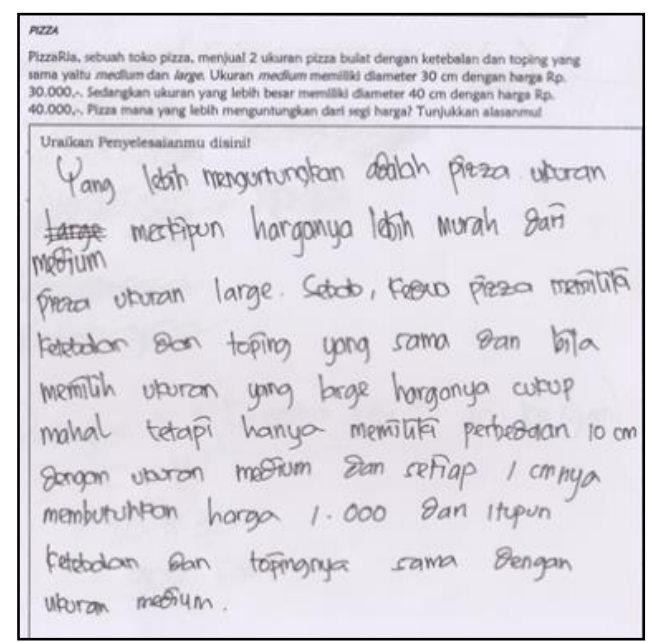

Figure 2. SC's Response on Social Context of PISA Problem

The given scaffolding is explaining type by asking subjects to read the questions carefully and make questions to themselves such as "what should I find or show you in this problem?". Then, the next stage is restructuring the problem-solving strategies .

\section{- Transformation error}

This mistake occurs in all contexts of PISA problem where two questions which get the most error is on social and scientific context. Subject make transformation error on scientific context when he solved the problem by applying the concept of percentage and multiplication. Then, he seemed confused when decided the given operation and the number in problem solving procedures. Hence, his strategy in problem solving unable to answer the question.

Fromthe interview, it was revealed that the subject made a mistake in transforming the mathematics PISA 2012. The subject problems can understand the questions well but the subject still can not choose the right strategy and a method to estimate. So that the the problem the subject is less precise although according to those asked 


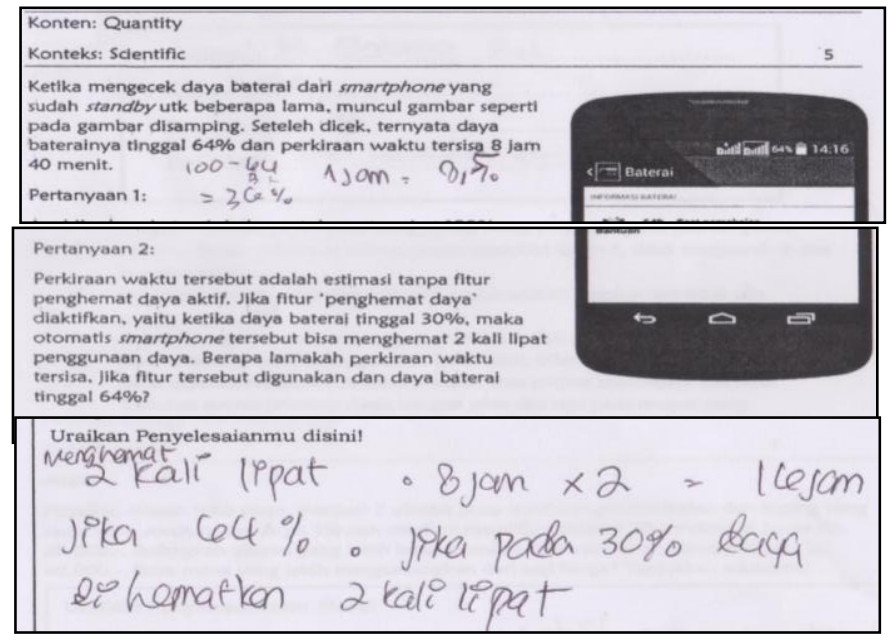

Figure 3. SB's Response on Saintific Context of PISA Problem

The form of the scaffoding given to subject SB on the type of the mistake of understanding problem is reviewing and restructuring. Subject is asked to correct the mistake in his work (reviewing) and arranging better solving strategies whether by using the pattern and making diagram or table to determine the proportion (restructuring). Therefore, subject does not experience the same mistake when facing problems which are equivalent with PISA 2012 problems.

\section{- Process Skill error}

This study suggest that the most error in process skill occurs on social and scientific context of PISA problem. In figure 3, SE do a mistake in multiplication process " $3.14 \mathrm{x}$ $30 \times 40=30 \mathrm{~cm}$ ". In interview process, SE stated that subject cancel out the same number are 3 and 4 such that 30 obtained from the calculation. In addition, subject also stated that his teacher commonly used thus method in division process so subject consider that cancel out method can be used in multiplication process. The form of given scaffolding areexplaining, reviewing and restructuring.

The form of the scaffoding given to subject SE on the type of the mistake of process skill is reviewing and restructuring. The combining scaffolding help subject another approach in solving PISA problem. First, subject is asked to identifiy the main informations which correlate with the solving strategy of the problem. Then, subject choose the right method in solving social context problem. The last, subject operate the given number accurately which is suitable with the solving strategy. Therefore, subject does not experience the same mistake when facing problems which are equivalent with PISA 2012 problems. 


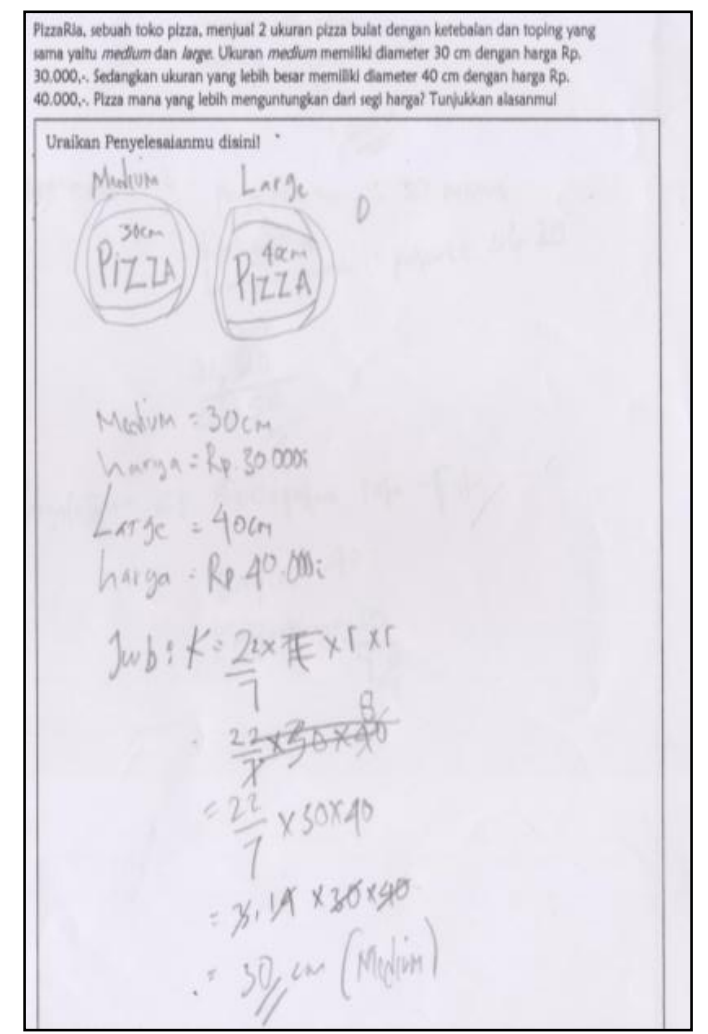

Figure 4. SE's Response on Social Context of PISA Problem

\section{- Encoding error}

Encoding error is a mistake when the subject write the final answer which is not accordance with what question ask. In this study, PISA context problem which getting the most error in encoding answer are social and scientific context.

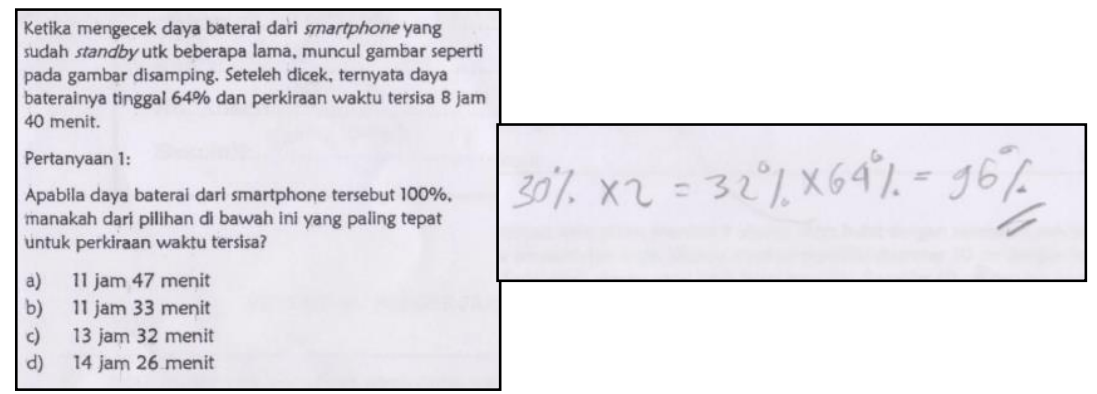

Figure 5. SE's Response on Scientific Context of PISA

Based on the subject work, the answer $96 \%$ is not accordance with what the problem ask about how long the remaining times in times unit. Based on the interview, subject consider that the answer of question 2 is about the percentage of the remaining time.

The form of the scaffoding given to subject SE on the type of the mistake of encoding is reviewing and restructuring. First, subject is asked to evaluate of his answer hence he can obtain the mistakes (reviewing). Then, subject improve his result by using evaluated steps and methods. Therefore, subject does not experience the same mistake when facing problems which are equivalent with PISA 2012 problems. 
Compare with other research which mainly focusing in error analysis based on Nemwan and its scaffolding is that Error Analysis in Solving Word Problem about Two Variable Linear Equations and Its Scaffolding Based on Newman Error Analysis on Students Grade VII of Malang State Junior High School (Rahayu and Qohar, 2014) shows that the type of error that had been done by their subject are comprehension, transformation, process skills and encoding. While the scafffolding that has been given to minimize their error are explaining, restructuring, and developing conceptual thinking. The error analysis in solving PISA problem has showed similar result where the subject do 5 mistakes based on Newman Error Analysis and its scaffolding up to restructuring stage.

From the research results obtained from the previous description, the authors to provide suggestions as follows: More varied in selecting research subjects can be based on cognitive style, learning style or type of student thinking. Conducting a thorough analysis of the data on each student who becomes the object of the data and compares the error analysis of the subject have the same error. Making further research or analysis of the students who make mistakes due to not accurately or error carelles and discussing the data about carelles error.

\section{Conclusion}

Based on the result, it is found that there are 5 types of mistakes made by the students namely reading error, comprehension error, transformation error, process skill error and encoding error. The most common mistake which are have been done by the subjects is encoding error with a percentage of $26 \%$. While reading is the fewest errors made by a subject that is only $12 \%$. Both transformation and process skill error possessed the same percentage of the number of errors is $24 \%$. The last, $14 \%$ of the made mistakes is an error in understanding the problem of PISA.

In this study, PISA problem is adopted from PISA 2012 where the predominant domain is mathematics. Thus, there are 4 selected PISA problem that each question has a different context namely social, personal, occupational and scientific. PISA Problem with the most errors is scientific context with a percentage of $43 \%$. Meanwhile, PISA with occupational context contains only 5 out of 42 errors. The rest, both personal and scientific context in succession problem has a percentage of error of $21 \%$ and $24 \%$.

The form of scaffolding in solving PISA problems are explaining, reviewing and restructuring. The activities in explaining type is asking subject to read the questions carefully and make a summary of new words and find the meaning of the word. Meanwhile, reviewing activities include asking the subjects to improve the results of the problems and restructuring student strategy in solving PISA 2012 problems.

Based on the conclusions, the writer can provide input for other researchers, teachers, students and schools. For other researchers, they need to analyse further onstudents error in solving PISA problems that have different content. As for teachers, it is required the learning of PISA types of problems in mathematics teaching so that students are familiar with the form of the question. In addition, students should also be open to their teachers if experiencing difficulty when doing on math problems.

\section{Acknowledgement}

This research is financially supported by Indonesian Directorate General of Higher Education (DIKTI). Essentially, this study is a part of research granted by PDP Grant "Penelitian Dosen Pemula Desentralisasi" DIKTI year 2016 with the number of contract $101 \mathrm{P} 2 \mathrm{H} / \mathrm{P} / \mathrm{K} 7 / \mathrm{KM} / 2016$. 


\section{Bibliography}

Australian Council for Educational Research. (2014). Newman's Error Analysis. PAT Resources Centre.

Cahyono, Adi Nur. (2010). Vygotskian Perspective: Proses Scaffolding untuk mencapai Zone of Proximal Development (ZPD) Peserta Didik dalam Pembelajaran Matematika. Yogyakarta, Makalah Seminar Nasional Matematika dan Pendidikan Matematika, 3(1).

Clements, M. A. (Ken). 1983. Analyzing Children's Error on Written Mathematical Tasks.

Gay, L. R., Mills, G. E. \& Airasian, P. (2011). Educational research: Competencies for analysis and applications (9th ed.).

Newman, M. A. (1977). An Analysis of Sixth-Grade Pupils' Error on Written Mathematical Tasks. Victorian Institute for Educational Research Bulletin, 39, 31-43.

OECD. (2010). PIS A 2009 Results: What Students Know and Can Do - Student Performance in Reading, Mathematics and Science (Volume I). OECD Publishing.

OECD. (2013a). PIS A 2012 Assessment and Analytical Framework: Mathematics, Reading, Science, and Problem Solving and Financial Literacy. OECD Publishing.

OECD.(2013b). PIS A 2012 Results in Focus: What 15 Year Olds Know and WhAt They Can do With What They Know. OECD Publishing.

Rahayuningsih, Puspita, Qohar, Abdul. (2014). Analisis Kesalahan Menyelesaikan Soal Cerita Sistem Persamaan Linear Dua Variabel (SPLDV) dan Scaffoldingnya Berdasarkan Analisis Kesalahan Newman Pada Siswa Kelas VIII SMP Negeri 2 Malang. Jurnal Pendidikan Matematika dan Sains Tahun II, No. 2, 109-116.

Shofan, Fiangga (2014) Tangram Game Activities, Helping The Students Difficulty In Understanding The Concept Of Area Conservation. Proceeding of International Conference On Research, Implementation And Education Of Mathematics And Sciences 2014

Stacey, Kaye. (2011). The PISA View of Mathematical Literacy in Indonesia. IndoMS, J.M.E, 2(2) , pp. $95-126$.

Wijaya, Ariyadi, Marja van den Heuvel-Panhuizen, Michiel Doorman, Alexander Robitzsch. (2014). Difficulties in solving context-based PISA mathematics tasks: An analysis of students' errors. The Mathematics Enthusiast, ISSN 1551-3440, 11(3), pp. 555-584.

Wijaya, Ariyadi. (2015).Kesalahan Siswa Dalam Memilah Data Relevan Pada Soal Matematika Berbasis Konteks. Prosiding Seminar Nasional Matematika dan Pendidikan Matematika, UMS, 2015, Surakarta: UMS Press. 